\title{
Pengaruh motivasi terhadap keberhasilan usaha para pedagang di Pasar Parit di Kuala Tungkal Jambi
}

\author{
Laras Wati*; Dahmiri; Sigit Indrawijaya
}

\author{
Program Studi Manajemen Fakultas Ekonomi dan Bisnis Universitas Jambi
}

*E-mail korespodensi: laraswti01@gmail.com

\begin{abstract}
The main subjective of this research is to analyze the description of the motivation and success of the trader's business and to analyze the influence of inspiration on the business success of traders in Pasar Part II Kuala Tungkal Jambi. The data used in this study is the primary data obtained by field research sourced from traders in Pasar Part II Kuala Tungkal Jambi as a sample. The sampling method used in this research is Purposive Random Sampling. Data were analyzed by descriptive quantitative analysis method. Data analysis tools use Simple Linear Regression. The study results found that the description of the trader's motivation was in an outstanding category with a score of 4,42. Meanwhile, in the definition of the success of the trades business is in the excellent category with a score of 4,18. Based on the simple linear regression analysis, the regression coefficient of the motivation variable is 0,600 with a probability value below 0,05 , which means that the motivation variable has a positive and significant effect on the business success of traders in Pasar Part II Kuala Tungkal Jambi.
\end{abstract}

Keywords : motivation, business success, simple linear regression analysis.

\begin{abstract}
Abstrak
Penelitian ini bertujuan untuk menganalisis gambaran motivasi dan keberhasilan usaha para pedagang dan menganalisis pengaruh motivasi terhadap keberhasilan usaha para pedagang di Pasar Parit II Kuala Tungkal Jambi. Data yang digunakan dalam penelitian ini adalah data primer yang diperoleh dengan cara penelitian lapangan yang bersumber dari pedagang di Pasar Parit II Kuala Tungkal Jambi sebagai sampel. Metode penarikan sampel yang digunakan dalam penelitian ini adalah Purposive Random Sampling. Data dianalisis dengan metode analisis deskriptif kuantitatif. Alat analisis data menggunakan regresi linier sederhana. Hasil penelitian karakteristik responden didefinisikan berdasarkan jenis kelamin, umur, tingkat Pendidikan, lama usaha, dan omset per bulan. Gambaran motivasi para pedagang dalam kategori tinggi. Sedangkan gambaran keberhasilan usaha para pedagang dalam kategori berhasil. Berdasarkan hasil analisis regresi linier sederhana koefisien regresi variabel motivasi sebesar 0,600 dengan nilai probabilitas di bawah 0,05, yang berarti variabel motivasi berpengaruh positif dan signifikan terhadap keberhasilan usaha para pedagang di Pasar Parit II Kuala Tungkal.
\end{abstract}

Kata kunci: motivasi, keberhasilan usaha, regresi linier sederhana.

\section{PENDAHULUAN}

Dalam era globalisasi salah satunya ditandai dengan semakin berkembangnya berbagai bidang usaha termasuk industri kecil dan menengah. Salah satu sektor yang menunjang perekonomian di indonesia berasal dari sektor Usaha Mikro Kecil Menengah (UMKM) karena melalui sektor inilah semua aspek yang berkaitan dengan 
pola kehidupan manusia bersumber, mulai dari sektor konsumsi, pangan, fashion, fotografer dan kesenian (Samuelson dkk dalam Munandar dkk, 2004).

Menurut Sutrisno (2012), UMKM mempunyai peran penting dalam pembangunan perekonomian dengan adanya kebijakan pemberdayaan ekonomi rakyat. Jika dilihat dari jumlah unit usahanya yang sangat banyak yang terdapat di semua sektor ekonomi dan kontribusinya yang besar terhadap kesempatan kerja dan pendapatan, khususnya didaerah pedesaan dan bagi keluarga berpendapatan rendah, tidak dapat diingkari betapa pentingnya UMKM bagi pembangunan ekonomi nasional sekaligus juga berperan sebagai motor penggerak yang sangat krusial bagi komunitas lokal. Salah satu langkah dalam mendukung tercapainya pembangunan nasional adalah pemberdayaan masyarakat melalui usaha kecil dan menengah (UKM). Pemberdayaan UKM di tengah arus globalisasi dan tingginya persaingan membuat UKM harus mampu menghadapi tantangan global seperti meningkatkan inovasi produk dan jasa, pengembangan sumber daya manusia dan teknologi, serta perluasan area pemasaran.

Menurut Nitisusastro (2013), wirausaha yang mengikuti pelatihan memiliki kemampuan dan keahlian dalam bidang manajemen (management skill) dibandingkan dengan wirausaha yang tidak mengikuti pelatihan. Pada dasarnya ketidak berhasilan UKM untuk berkembang bukan hanya disebabkan oleh kendala modal usaha. Tetapi banyak faktor penyebabnya bisa diperoleh melalui berbagai program pelatihan dan pendampingan. Berdasarkan permasalahn tersebut diperlukan motivasi dalam mengembangkan sebuah usaha yang telah diciptakan selain dari sebuah tuntutan untuk dapat memenuhi kebutuhan sehari-hari. Menurut teori hierarki yang dikembangkan (Sutrisno, 2012) individu dalam memenuhi kebutuhan hidup didasarkan pada motivasi berdasarkan klasifikasi kebutuhan. Menurut Rusyidi (2011), kebutuhan unuk mempertahankan hidup, maka mendorong orang untuk mengerjakan suatu pekerjaan, karena dengan bekerja akan mendapatkan imbalan yang akan digunakan untuk memenuhi kebutuhan tersebut. Motivasi merupakan proses keterkaitan antara usaha dan salah satu pendorong tumbuh kembangnya jiwa wirausaha. Motivasi berkaitan dengan sebuah keinginan dan minat dari dalam diri untuk melakukan sesuatu, jika seseorang yang termotivasi dapat menumbuhkan kreatifitas dan inovasi.

Wirausahawan melihat potensi yang dilihat kebanyakan orang sebagai masalah atau bahkan yang tidak dipikirkan sama sekali oleh kebanyakan orang, wirausahawan lebih tertarik mencari dan memanfaatkan peluang. Memiliki perusahan sendiri memberikan kebebasan dan peluang bagi para wirausahawan untuk mencapai apa yang penting baginya. Para wirausahawan ingin (mencoba memenangkan) hidup mereka, dan mereka menggunakan bisnis mereka untuk mewujudkan keinginan mereka. Kesepakatan bisnis berdasarkan kepercayaan dan saling menghormati adalah ciri perusahaan kecil. Para pemilik perusahaan kecil menyukai kepercayaan dan pengakuan yang diterina dari pelanggan yang telah mereka layani dengan setia selama bertahuntahun.

Menurut Danil (2013) mengartikan kewirausahaan sebagai suatu proses penerapan kreativitas dan inovasi dalam memecahkan persoalan dan menemukan peluang untuk memperbaiki kehidupan (usaha). Pelaku usaha yang telah memiliki motivasi dalam menjalakan usaha akan mampu berpikir inovatif serta memiliki semangat dalam mengembangkan usaha yang dirintis. Inovasi sebagai keberhasilan ekonomi berkat adanya pengenalan cara baru atau kombinasi baru dari cara-cara lama dalam mentranformasi input menjadi output (teknologi) yang menghasilkan perubahan besar 
dan drastis dalam perbandingan antara nilai guna yang dipersiapkan oleh konsumen atas manfaat suatu produk (barang atau jasa) dan harga yang ditetapkan oleh produsen.

Menurut Amalia dan Murni (2014), keberhasilan usaha adalah tujuan utama dari dari sebuah perusahaan atau bisnis yang segala aktivitas di dalamnya ditunjukan untuk mencapai suatu keberhasilan atau kesuksesan. Dalam pengertian umum, keberhasilan menunjukan suatu keadaan yang lebik baik atau unggul dari pada masa sebelumnya. Keberhasilan usaha dapat dilihat dari suatu keadaan yang menggambarkan lebih dari pada yang lainnya yang sederajat kelasnya. Kemampuan untuk belajar dari pengalaman baru membuat pengusaha mendapatkan umpan balik yang dapat digunakan untuk memperbaiki produk bahkan mengembangkan usaha (Muana, 2005).

Menurut Mankiw (2006), pasar tradisional merupakan institusi ekonomi yang berperan dalam pertukanan jual beli barang yang dilakukan oleh pembeli atau pedagang. Harapan pedagang adalah menawarkan barang yang dijual sehingga menerima imbalan berupa uang. Pedagang dan pembeli melakukan tawar menawar hingga terjadi kesepakatan harga. Pedagang dapat diartikan sebagai orang yang menawarkan barang dagangannya yang tidak diproduksi sendiri untuk memperoleh keuntungan. Pedagang tradisonal pasar sayur merupakan pedagang yang menjual sayur yang dibeli dari pemasok untuk di jual kembali.

Di pasar Parit II terdapat berbagai macam pedagang yang menjual berbagai kebutuhan rumah tangga, seperti pedagang sayur, pedagang ikan dan lain lain. Jika dilihat dari jumlah pedagang yang berada di pasar Parit II memiliki peranan besar terhadap kegiatan pasar karena mereka memiliki peran sebagai pedagang sayur, pedagang ikan, pedagang daging ayam, pedagang pakaian, pedagang beras, pedagang kelontong, pedangang telor, dan pedagang lain-lainnya. Pedagang yang biasanya berdagang di pasar Parit II merupakan pedagang yang membeli barang dagangan dari pemasok luar daerah untuk di jual kembali. Pedagang yang berjualan merupakan warga setempat yang rumahnya strategis sebagai lapak untuk berjualan. Sebagian besar mata pencaharian di pasar Parit II. Untuk memenuhi kebutuhan pasar atau masyarakat yang jaraknya jauh dari pasar maka dibentuklah pasar Parit II yang mayoritas berdagang adalah wanita.

Kebutuhan sayur-mayur di pasar tradisional Kuala Tungkal, Kabupaten Tanjung Jabung Barat, sebagian besar dipasok dari luar daerah hanya beberapa kecamatan di Tanjung Jabung Barat yang menyuplay sayur-mayur kepasar-pasar kuala tungkal yakni Seberang Kota, Parit Pudin (Bram Itam) dan Pangkal Babu, hanya saja belum terpenuhi, sebagian besar sayur di kota Tungkal di datangkan dari kota Jambi. Sebagai seorang wirausaha pemula maupun pengusaha muda didalam dunia bisnis tidak terlepas dari inspirasi serta motivasi yang menjadikan mereka untuk terus melangkah tanpa henti. Trik paling ampuh dengan gaya yang berbeda-beda setiap orang dalam meraih kesuksesan adalah hak pribadi yang tidak bisa diganggu oleh siapapun. Namun, tidak jarang orang yang tengah berusaha hampir mencapai keberhasilan merasa lelah dan putus asa, sehingga usaha yang sudah dirintis dalam waktu lama mengalami kerugian dan gulung tikar. Sukses adalah dambaan siapapun tidak mungkin dapat diraih tanpa didukung keseriusan serta fokus terhadap apa yang dibangun. Banyak pengusaha yang tidak mencapai keberhasilan dengan baik karena kurang bias mengatur keuangan dengan baik. Maka dari itu, sebagai wirausaha harus memiliki pengatahuan yang baik dalam mengatur keuangan usaha dalam berbisnis. Usaha dagang sangat cocok dilakukan karena barang yang cepat bermanfaat bagi penggunanya. 


\section{METODE}

\section{Jenis penelitian}

Sumber data yang dipergunakan dalam penelitian ini berupa data primer dan data sekunder. Jenis penelitian dengan memperoleh dari data primer dan data sekunder. Data primer adalah data-data yang diperoleh langsung dari responden penelitian di lapangan. Data yang digunakan dalam penelitian ini adalah data yang diperoleh langsung dari pedagang di Pasar Parit II Kuala Tungkal Jambi berupa persepsi responden tentang keberhasilan usaha. Data sekunder merupakan data yang diperoleh secara tidak langsung melalui media perantara. Data yang diperoleh dari pihak tertentu berupa data jumlah pedagang di Pasar Parit II Kuala Tungkal Jambi. Data juga diperoleh dari penelitian perpustakaan yang dilakukan untuk mendapatkan data berupa teori-teori, konsep-konsep, definisi-definisi, serta data tentang perusahaan yang berhubungan dengan topik penelitian ini data juga diperoleh dari artikel yang sudah di publikasikan seperti buku, jurnal elektronik dan juga penelitian terdahulu. Data sekunder dapat diperoleh melalui data yang telah tersaji pada dokumen suatu instansi dan kantor yang telah menginput data secara tersusun dan terstruktur dalam kurun waktu tertentu.

\section{METODE}

\section{Data primer} berikut:

Teknik pengumpulan data primer dilakukan dengan beberapa metode sebagai

\section{Wawancara (Interview)}

Wawancara digunakan sebagai teknik pengumpulan data apabila peneliti ingin melakukan studi pendahuluan untuk menemukan permasalahan yang harus diteliti, dan juga apabila peneliti ingin mengetahui hal-hal dari responden yang mendalam dan jumlah respondennya sedikit atau kecil.

Melakukan tanya jawab langsung dengan responden mengenai keberhasilan usaha dan hal-hal lain yang berhubungan dengan penelitian ini. Tujuanya adalah untuk mendapatkan tambahan informasi mengenai penelitian yang sedang dilakukan melalui dimensi variabel antara lain : motivasi, inovasi dan keberhasilan usaha.

\section{Kuisioner}

Kuisioner yaitu cara memperoleh data primer yang terstruktur dengan cara menggunakan daftar pertanyaan tertutup yang diberikan kepada responden. Dalam penelitian ini, kuisioner itu berisikan tentang pernyataan dimana alternatife pilihan jawabannya telah tersedia kuisioner yang digunakan memuat butir-butir pernyataan mengenai tanggapan pedagang terhadap keberhasilan usaha. Hasil tanggapan responden tersebut akan diberikan nilai atau bobot secara bertingkat berdasarkan skala likert. Apabila dirangkaikan maka penyusunannya dimulai dari sangat tidak setuju sampai dengan sangat setuju. Rentang yang demikian akan menghasilkan data yang dapat diolah kedalam penelitian lebih lanjut.

Kuisioner yaitu suatu pengumpulan data dengan memberikan atau menyebarkan daftar partanyaan ataupun pernyataan kepada responden dengan harapan responden merespon daftar pertanyaan atau pernyataan tersebut. Instrumen dalam penelitian ini bersifat terbuka dan tertutup. Pertanyaan terbuka adalah jika jawaban tidak disediakan 
sebelumnya, sedangkan pertanyaan tertutup adalah jika alternatif-alternatif jawaban telah disediakan (Umar, 2003).

Kuesioner merupakan teknik pengumpulan data yang dilakukan dengan cara memberi seperangkat pertanyaan atau pernyataan tertulis kepada responden. Jenis kuesioner dalam penelitian ini adalah open closed question yaitu pertanyaan terbuka tertutup. Dalam hal ini responden tinggal memilih jawaban-jawaban yang tersedia didalam kuesioner tapi responden juga diberikan kesempatan untuk mengutarakan jawabannya sesuai pertanyaan yang telah disediakan.

\section{Data sekunder}

Data sekunder diperoleh melalui studi pustaka, mempelajari literatur dan jurnal, pencarian melalui media internet guna memperoleh buku-buku untuk mendapatkan konsep-konsep dan definisi-definisi yang berhubungan dengan penelitian.

\section{Metode penarikan sampel}

Menurut Sugiyono (2014), Populasi adalah wilayan generalisasi yang terdiri atas objek atau subjek yang mempunyai kualitas dan karakteristik tertentu yang ditetapkan oleh peneliti untuk dipelajari dan kemudian ditarik kesimpulannya. Daerah penelitian yang dipilih yaitu Pasar Parit II Kuala Tungkal dengan secara sengaja (purposive). Pertimbangan daerah tersebut dijadikan sebagai lokasi penelitian adalah berdasarkan data Dinas Perdagangan dan Pengelolaan Pasar Kabupaten Tanjung Jabung Barat.

Adapun populasi dalam penelitian ini adalah pedagang di Pasar Parit II Kuala Tungkal Jambi dengan jumlah 57 orang. Dengan diketahui jumlah populasi penelitian ini, maka pengambilan jumlah sampel penelitian ini dilakukan dengan sensus. Sensus merupakan penelitian yang dianggap dapat mengungkapkan ciri-ciri populasi (parameter) secara akurat dan komprehensif, sebab dengan menggunakan seluruh unsur populasi sebagai sumber data, maka gambaran tentang populasi tersebut secara utuh dan menyeluruh akan diperoleh. Maka jumlah sampel yang akan diteliti dalam penelitian ini adalah sebanyak populasi yaitu 57 orang pedagang.

\section{Populasi}

Populasi merupakan keseluruhan dari unit anilisa yang ciri-cirinya akan diduga. Populasi adalah sejumlah individu yang paling sedikit mempunyai sifat atau kepentingan yang sama. Populasi adalah gabungan dari seluruh elemen yang berbentuk peristiwa, hal atau orang yang memiliki karakteistik yang serupa yang menjadi pusat perhatian seorang peneliti karena itu dipandang sebagai sebuah semesta penelitian. Populasi dalam penelitian ini adalah 57 orang pedagang di Pasar Parit II Kuala Tungkal Jambi.

\section{Sampel}

Menurut Sugiyono (2014), sampel adalah bagian dari jumlah dan karakteristik yang dimilki oleh populasi. Sampel menrupakan bagian yang berguna bagi tujuan penelitian populasi dan aspek-aspeknya. Sampel yang digunakan dalam penelitian ini adalah seluruh populasi yaitu seluruh pedagang di Pasar Parit II Kuala Tungkal Jambi dengan metode survey sebanyak 57 orang. Metode ini merupakan metode purposive atau sengaja pada obyek yang ada pada suatu populasi yang kemudian dijadikan sebuah sampel penelitian. 


\section{Metode analisis data}

\section{Analisis deskriptif}

Statistik deskriptif adalah statistik yang digunakan untuk menganalisis data dengan cara mendeskripsikan atau menggambarkan data yang telah terkumpul sebagaimana adanya tanpa bermaksud membuat kesimpulan yang berlaku untuk umum atau generalisasi (Sugiyono, 2014).

Analisis Deskriftif berhubungan dengan pengumpulan dan peringkasan data, serta penyajian hasil peringkasan tersebut. Analisis Deskriftif sangat bermanfaat untuk menganalisis data populasi atau untuk menganalisis kajian atau penelitian yang obyeknya berupa populasi. Analisis Deskriftif adalah suatu metode yang berfungsi untuk membuat gambaran secara sitematis dan faktual mengenai fakta-fakta yang ada dilapangan dengan berdasarkan kepada teori-teori, konsep-konsep, yang ada diliteratur yang terkait dengan penelitian ini. Dimana prosedur gejala dan hubungan-hubungannya definisikan, diklasifikasikan, dan dikategorikan (Umar, 2005).

Analisis deskriptif dilakukan untuk menyusun tabel frekuensi distribusi untuk mengetahui apakah tingkat perolehan nilai (Skor) variabel yang diteliti masuk ke dalam kategori sangat tinggi, tinggi, sedang, rendah dan sangat rendah. Untuk mengkategorikan skor tiap indikator maupun variabel penelitian yakni apakah termasuk kategori baik hingga sangat baik maka digunakan metode mengklasifikasikan berdasarkan posisi dari nilai di dalam skala rentang.

Untuk menentukan skala digunakan rumus sebagai berikut :

Penentuan Rentang Skala

$$
R S=n \frac{(M-1)}{M}
$$

Dimana :

RS = Rentang skala

$\mathrm{n} \quad$ = Jumlah sampel

$\mathrm{m}$ = Jumlah alternatif jawaban Item

$$
\begin{aligned}
& \mathrm{RS}=57 \frac{(5-1)}{5} \\
& \mathrm{RS}=46
\end{aligned}
$$

$$
\begin{aligned}
\text { Penentuan Rentang Skor } & \\
\text { Rentang skor terendah } & =\mathrm{n} \times \text { skor terendah } \\
& =46 \times 1 \\
\text { Rentang skor terendah } & =\mathrm{n} \times \text { skor terendah } \\
& =46 \times 5 \\
& =230
\end{aligned}
$$

Alternatif jawaban dengan skala likert kuesioner dalam penelitian ini diberikan kepada para pedagang di Pasar Parit II Kuala Tungkal sebagai sumber data ordinal, namun data sementara yang diperoleh masih berupa data interval menggunakan Method of Succesive Interval (MSI).

Karena skala yang digunakan dalam penelitian ini adalah skala likert $1-5$, maka kategori pengklasifikasian untuk variabel dapat dilihat pada tabel berikut : 
Tabel 1. Keputusan penilaian pengisian kuesioner

\begin{tabular}{clc}
\hline Simbol & Keputusan Jawaban & Nilai \\
\hline SS & Sangat Setuju & 5 \\
S & Setuju & 4 \\
AS & Agak Setuju & 3 \\
TS & Tidak Setuju & 2 \\
STS & Sangat Tidak Setuju & 1 \\
\hline
\end{tabular}

Sumber : Umar (2005)

Rata-rata jawaban yang diperoleh dilapangan melalui penyebaran angket/kuesioner diolah menjadi data interval yang tersusun secara terstruktur guna memperoleh data yang akan diolah dapat relevan. Mean atau nilai tengah data yang disebar itu menjadi standar dalam perolehan data interval untuk mempermudahkan penyusunan datanya. Setelah melalui serangkaian data interval melalui skala likert yang dirumuskan dari 5 poin pernyataan berikut :

Interval $=\frac{\text { nilai terting } i-\text { nilai terendah }}{\text { nilai terting } i}=\frac{5-1}{5}=0,8$

Hasil persamaaan itu digunakan untuk menentukan rentang pada masing-masing indikator pernyataan untuk memperoleh rata-rata nilai interval tersebut. Adapun masing-masing rentang nilai itu adalah :

$1,00-1,80=$ Termasuk kategori negatif (Sangat Tidak Baik)

$1,81-2,60=$ Termasuk kategori negatif (Tidak Baik)

$2,61-3,40=$ Termasuk kategori Biasa $($ Sedang)

$3,41-4,20=$ Temasuk kategori positif (Baik)

$4,21-5,00=$ Termasuk kategori positif (Sangat Baik)

Data ordinal yang diperoleh dari penyebaran angket/kuesioner kepada responden secara tertutup dari pernyataan-pernyataan yang tersedia dengan menggunakan skor kusioner merupakan langkah yang harus ditempuh dalam penelitian berupa data ordinal. Langkah dalam pengolahan penelitian dari data ordinal memerlukan waktu dan kecermatan menidentifikasi jawaban dari pernyataan responden.

Penggunaan data interval berupa hasil skor-skor pernyataan dari jawaban secara tertutup oleh responden membantu penulis memperoleh data dengan standar nyata yang terjadi dilapangan. Memang langkah ini ditempuh untuk menghasilkan sebuah penelitian yang akurat sesuai obyek yang diteliti dengan memasukkan ke microsoft excel.

\section{Analisis kuantitatif}

Analisis kuantitatif adalah analisis yang menggunakan model-model, seperti model matematika (statistic, econometric). Hasil analisis disajikan dalam bentuk angka- 
angka yang kemudian dijelaskan dan diinterpretasikan dalam suatu uraian menggunakan alat analisis berganda melalui SPSS 26.0.

Apabila data yang dikumpulkan itu berjumlah besar dan mudah diklasifikasi ke dalam kategori-kategori tertentu, maka analisis kuantitatiflah yang harus dikerjakan. Analisis kuantitatif itu di sebut juga analisis statistik, bagaimanpun juga adalah kegiatan yang dituntun secara sadar oleh disiplin, kecermatan dan ketelitian. Namun demikian hendaklah diingat bahwa kelebihan dalam hal kecermatan (accuracy) ini tidaklah berarti bahwa pada analisis kuantitatif itu selalu ada kelebihan dalam hal derajat kebenarannya (validity) apabila pengolahan data, penggunaan data tidak tepat (Sugiyono, 2014). Sebagai penerapan penelitian dengan data-data yang terkolektif pada penelitian yang fokus pada para pedagang di Pasar Parit II Kuala Tungkal Jambi secara keseluruhan.

\section{Uji validitas}

Uji validitas digunakan untuk mengukur sah atau tidaknya suatu kuesioner. Suatu kuesioner dikatakan valid jika pernyataan pada kuesioner mampu mengungkapkan sesuatu yang akan diukur dari kuesioner tersebut. Valid atau tidaknya alat ukur tersebut dapat diuji dengan mengkorelasikan antara skor butir pertanyaan dengan skor total variabel (Ghozali, 2008).

Didalam penelitian ini uji coba dilakukan terhadap 57 responden. Perhitungan uji validitas dilakukan dengan program SPSS Statistics 26. Uji signifikan dilakukan dengan membandingkan nilai $\mathrm{r}_{\text {hitungdengan }} \mathrm{r}_{\text {tabel. }}$. Untuk degree of freedom $(d f)=\mathrm{n}-2$, dalam hal ini $\mathrm{n}$ adalah jumlah sampel. Apabila $d f=\mathrm{n}-2=7-2=5$ dan alpha 0,05 (5\%), maka $r_{\text {tabel }}=0,25$. Suatu indikator dikatakan valid dengan ketentuan (Ghozali, 2008):

Hasil rhitung $>$ rtabel $(0,25)=$ valid

Hasil rhitung $<\operatorname{rtabel}(0,25)=$ tidak valid

Hasil validitas dapat dilihat pada tampilan Item-Total Statistics pada kolom Corrected Item-Total Correlation.

\section{Uji reliabilitas}

Reliabilitas adalah derajat ketepatan, ketelitian, atau keakuratan yang ditunjukkan oleh instrumen pengukuran. Uji reliabilitas juga dapat dikatakan sebagai suatu alat yang digunakan untuk mengukur suatu kuesioner yang merupakan indikator dari variabel. Uji reliabilitas dapat dilakukan dengan menggunakan program SPSS dengan memilih menu analyze,kemudian pilih sub menu scale, lalu pilih reliability analysis. Hasil analisis tersebut akan diperoleh melalui hasil statistik cronbach alpha $(\alpha)$. Suatu variabel dikatakan reliable jika memberikan nilai cronbach alpha > 0,60 (Ghozali, 2008). Indikator pengukuran reliabilitas yang terbagi dalam tingkatan reliabelitas dengan kriteria sebagai berikut, jika alpha atau r hitung :

0,8-1,0 = Reliabilitas baik

0,6-0,799= Reliabelitas diterima secara moderat

Kurang dari 0,6 = Reliabilitas kurang baik

Semakin tinggi nilai alphanya mendekati satu maka nilai reliabilitas datanya semakin terpercaya. Hal ini menunjukkan adanya tingkat kepercayaan yang mampu meningkatkan penelitian lebih lanjut untuk dilaksanakan pada tingkat yang lebih koprehensif lagi. 


\section{Alat analisis data}

\section{Analisis regresi linier sederhana}

Alat analisis yang dimaksud untuk melihat sejauh mana pengaruh motivasi terhadap keberhasilan usaha pedagang di Pasar Parit II Kuala Tungkal Jambi. Hipotesis penelitian akan diuji dengan menggunakan analisis regresi linear berganda. Analisis regresi sederhana merupakan hubungan anatara dua atau lebih variabel yaitu bebas (variabel independen) dan variabel terikat (variabel dependen).

Perumusan regresi pada penelitian ini dapat dirumuskan sebagai berikut :

$\mathrm{Y}=\mathrm{a}+\mathrm{bX}+\mathrm{e}$

Dimana,

Y : Variabel dependen (keberhasilan usaha)

a : Konstanta

b : Koefisien Regresi

X : Motivasi

e : Eror term.

\section{Pengujian hipotesis}

Untuk menjawab hipotesis dalam penelitian ini, maka digunakan:

\section{Uji parsial (uji t)}

Menurut Ghozali (2008), uji stastistik t pada dasarnya menunjukkan seberapa jauh pengaruh satu variabel independen secara individual dalam menerangkan variabel dependen. Pengujian dilakukan dengan menggunakan significance level 0,05 $(\alpha=5 \%)$.Uji ini digunakan untuk mengetahui seacara parsial seberapa pengaruh tingkat signifikan variabel bebas (independen) terhadap variabel terikat (dependen). Merupakan pengujian signifikasi koefisien regresi parsial dengan kriteria $t$ statistik. Ketentuan tingkat kepercayaan $\alpha=90 \%$ adalah uji dua arah hipotesis :

$$
\begin{aligned}
& \mathrm{H}_{0}=\beta_{1}=\beta_{2} \\
& \mathrm{H} \alpha=\beta_{1} \neq \beta_{2}
\end{aligned} \quad \mathrm{t}_{\text {hitung }}=\frac{\beta 1}{\operatorname{Se}(\beta 1)}
$$

Dimana :

$\mathrm{T} \quad: \mathrm{t}$ - hitung

$\beta 1 \quad$ : Koefisien regresi

$\mathrm{Se} \quad$ : Standar error

Dengan membandingkan t-hitung dan t-tabel pada tingkat keyakinan tertentu dapat diambil kesimpulan dengan kriteria sebagai berikut :

Jika t-hitung $>$ t-tabel, yang berarti variasi variabel mampu menerangkan variasi variabel terikat. Hal ini berarti bahwa variabel independen $(\mathrm{X})$ yaitu motivasi $(\mathrm{Y})$ yaitu peningkatan standar usaha.

Jika t-hitung < t-tabel, yang berarti secara individu variasi variabel bebas tidak mampu menjelaskan variabel-variabel terikat. Hal ini berarti bahwa variabel independen (X) motivasi (Y) yaitu peningkatan standar usaha. 


\section{HASIL DAN PEMBAHASAN}

\section{Karakteristik responden berdasarkan jenis kelamin}

Jenis kelamin merupakan status kelamin yang dimiliki pedagang. Karakteristik responden berdasarkan jenis kelamin pedagang di Pasar Parit II Kuala Tungkal Jambi dapat di lihat sebagai berikut :

Tabel 2. Karakteristik responden berdasarkan jenis kelamin

\begin{tabular}{ccc}
\hline Jenis kelamin & Jumlah & Persentase \\
\hline Laki-laki & 22 & 38,60 \\
Perempuan & 35 & 61,40 \\
Total & 57 & 100,00 \\
\hline
\end{tabular}

Sumber : Data diolah, 2021

Berdasarkan Tabel 2. menjelaskan bahwa dari 57 respondenpedagang di Pasar Parit II Kuala Tungkal Jambi dengan jenis kelamin laki-laki menunjukkan jumlah sebanyak 22 orang atau $38,60 \%$, sedangkan yang berjenis perempuan sebanyak 35 orang atau $61,40 \%$. Hal ini menunjukkan bahwa sebagian besar responden dalam penelitian ini adalah jenis kelamain perempuan.

\section{Karakteristik responden berdasarkan jenis umur}

Umur merupakan salah satu faktor yang terdapat dalam karakteristik responden. Digunakan untuk mengetahui perbandingan antara kemampuan pengrajin di Kecamatan Tungkal Ilir). Karakteristik responden berdasarkan umur pedagang di Pasar Parit II Kuala Tungkal Jambi dapat di lihat sebagai berikut :

Tabel 3. Karakteristik responden berdasarkan umur

\begin{tabular}{ccc}
\hline Umur (Tahun) & Jumlah & Persentase \\
\hline $17-25$ & 12 & 21,05 \\
$26-34$ & 19 & 33,33 \\
35 ke atas & 26 & 45,62 \\
Total & 57 & 100,00 \\
\hline
\end{tabular}

Sumber : Data diolah, 2021

Berdasarkan Tabel 3 menjelaskan bahwa dari 57 responden pedagang di Pasar Parit II Kuala Tungkal Jambi dengan umur 17 - 25 tahun menunjukkan jumlah sebanyak 12 orang atau $21,05 \%$, dan umur 26 - 34 tahun sebanyak 19 orang atau $33,33 \%$, sedangkan yang umur 35 tahun ke atas sebanyak 26 orang atau 45,62\%. Hal ini menunjukkan bahwa sebagian besar responden dalam penelitian ini adalah memiliki umur 35 tahun ke atas.

\section{Karakteristik responden berdasarkan tingkat pendidikan}

Tingkat Pendidikan Seseorang tidak terlalu berpengaruh terhadap pedagang yang berjualan justru mereka hanya membutuhkan keahlian dan keterampilan dalam menyiapkan modal untuk belanja bahan-bahan jualan. Karakteristik respon berdasarkan tingkat pendidikan pedagang di Pasar Parit II Kuala Tungkal Jambi sebagai berikut : 
Tabel 4. Karakteristik responden berdasarkan tingkat pendidikan

\begin{tabular}{ccc}
\hline Tingkat Pendidikan & Jumlah & Persentase \\
\hline SD & 4 & 7,02 \\
SLTP & 10 & 17,54 \\
SLTA & 38 & 66,67 \\
S1 & 5 & 8,77 \\
Total & 57 & 100,00 \\
\hline
\end{tabular}

Sumber : Data diolah, 2021

Berdasarkan Tabel 4 menjelaskan bahwa dari 57 responden pedagang di Pasar Parit II Kuala Tungkal Jambi dengan tingkat pendidikan SD, SLTP, dan SLTA dan tingkat perguruan tinggi (S1) semuanya menjadi responden, dengan responden tingkat pendidikan SD menunjukkan jumlah sebanyak 4 orang atau 7,02\%, tingkat pendidikan SLTP berjumlah 10 orang atau 17,54\%, tingkat pendidikan SLTA berjumlah 38 orang atau $66,67 \%$ dan tingkat pendidikan perguruan tinggi untuk S1 sebanyak 5 orang atau $8,77 \%$. Hal ini menunjukkan bahwa mayoritas responden dalam penelitian ini adalah tingkat pendidikan SLTA.

\section{Karakteristik responden berdasarkan lama usaha}

Lama usaha yang dimiliki oleh pedagang untuk berjualan di pasar yang menunjukkan lama usaha yang diperoleh dari pengalaman selama kurun waktu tertentu. Karakteristik responden berdasarkan lama usaha pedagang di Pasar Parit II Kuala Tungkal Jambi sebagai berikut :

Tabel 5. Karakteristik responden berdasarkan lama usaha

\begin{tabular}{ccc}
\hline Lama usaha (Tahun) & Jumlah & Persentase (\%) \\
\hline $1-5$ & 27 & 47,36 \\
$6-10$ & 18 & 31,57 \\
11 ke atas & 12 & 21,07 \\
Total & 57 & 100,00
\end{tabular}

Sumber : Data diolah, 2021

Berdasarkan Tabel 6 menjelaskan bahwa dari 57 responden pedagang di Pasar Parit II Kuala Tungkal Jambi dengan lama usaha 1 - 5 tahun menunjukkan jumlah sebanyak 27 orang atau 47,36\%, dan lama usaha6 - 10 tahun sebanyak 18 orang atau $31,57 \%$, sedangkan yang lama usaha 11 tahun ke atas sebanyak 12 orang atau 21,07\%. Hal ini menunjukkan bahwa mayoritas responden dalam penelitian ini adalah lama usaha 11 tahun ke atas.

\section{Karakteristik responden berdasarkan omset per bulan}

Pendapatan pedagang dalam omset per bulan itu bervariasi yaitu tergantung pada besar kecilnya hasil yang diperoleh dengan modal usaha yang sangat mendukung. Karakteristik responden berdasarkan pedagang di Pasar Parit II Kuala Tungkal Jambi sebagai berikut : 
Tabel 7. Karakteristik responden berdasarkan omset per bulan

\begin{tabular}{ccc}
\hline Omset Per Bulan (Rp) & Jumlah Responden & Persentase (\%) \\
\hline$<3.000 .000$ & 14 & 24,56 \\
$3.100 .000-4.000 .000$ & 13 & 22,80 \\
$>4.100 .000$ & 30 & 52,64 \\
Total & 57 & 100,00 \\
\hline
\end{tabular}

Sumber : Data diolah, 2021

Berdasarkan Tabel 7 menjelaskan bahwa dari 57 responden pedagang di Pasar Parit II Kuala Tungkal Jambi dengan omset per bulankurang dari Rp3.000.000,menunjukkan jumlah sebanyak 14 orang atau $24,56 \%$, dan omset per bulan antara Rp 3.100 .000 - 4.000.000,- sebanyak 13 orang atau 22,80\%, sedangkan yang omset per bulan lebih dari Rp 4.100.000,- sebanyak 30 orang atau 52,64\%. Hal ini menunjukkan bahwa mayoritas respondenpedagang di Pasar Parit II Kuala Tungkal Jambi dalam penelitian ini adalah denganomset per bulan lebih dari Rp 4.100.000,-.

\section{Analisis regresi linier berganda}

Penelitian ini meneliti tentang pengaruh motivasi terhadap keberhasilan usaha para pedagang di Pasar Parit II Kuala Tungkal Jambi dengan variabel bebas yang mempengaruhi variabel terikat dengan cara menyebarkan angket sebagai data yang kemudian diolah dengan menggunakan SPSS versi 24. Hasil dari pengolahan data dapat dilihat pada tabel berikut :

Tabel 8. Hasil regresi linier berganda

\begin{tabular}{|c|c|c|c|c|c|c|c|c|}
\hline & \multirow{3}{*}{ Model } & & & \multirow{3}{*}{$\begin{array}{c}\begin{array}{c}\text { Coefficients } \\
\text { Standardized } \\
\text { Coefficients }\end{array} \\
\text { Beta }\end{array}$} & \multirow{3}{*}{$\mathbf{T}$} & \multirow{3}{*}{ Sig. } & \multirow{2}{*}{\multicolumn{2}{|c|}{ Collinearity Statistics }} \\
\hline & & \multicolumn{2}{|c|}{$\begin{array}{c}\text { Unstandardized } \\
\text { Coefficients }\end{array}$} & & & & & \\
\hline & & B & $\begin{array}{c}\text { Std. } \\
\text { Error }\end{array}$ & & & & Tolerance & VIF \\
\hline 1 & (Constant) & 13.976 & 2.567 & & 5.445 & .000 & & \\
\hline & Motivasi & .600 & .112 & .586 & 5.368 & .000 & .040 & 11.450 \\
\hline
\end{tabular}

Sumber : Data diolah, 2021

Hasil pengolahan data dengan menggunakan SPSS versi 24 diperoleh regresi linier sederhana untuk menghitung keberhasilan usaha para pedagang di Pasar Parit II Kuala Tungkal Jambi yang di pengaruhi dengan variabel bebas yaitu motivasi, maka diperoleh persamaan regresi sebagai berikut:

$$
\begin{aligned}
& Y=\beta_{0}+\beta_{1} X+e^{u} \\
& Y=13,976+0,600 X
\end{aligned}
$$

Hasil pengolahan data di peroleh nilai konstanta sebesar 13,976 yang berarti jika motivasi tetap maka keberhasilan usaha para pedagang sebesar 13,976. Koefisien regresi motivasi sebesar 0,600 maka apabila motivasi mengalami peningkatan 1 satuan maka keberhasilan usaha para pedagang sebesar 0,6 .

Berdasarkan hasil pengolahan data dengan regresi linier sederhana bahwa keberhasilan usaha para pedagang akan meningkat diperoleh dari koefisien regresi 
variabel motivasi sebesar 0,600 pada tingkat signifikansi 0,000 di bawah 0,05 yang artinya bahwa variabel motivasi berpengaruh posistif dan signifikan terhadap keberhasilan usaha para pedagang di Pasar Parit II Kuala Tungkal Jambi.

Hasil analisis ini dapat diketahui bahwa motivasi membawa pengaruh dalam suatu keberhasilan usaha, dimana motivasi itu mendorong seorang pedagang untuk menjalankan usahanya dengan perhitungan manajemen yang baik. Sehingga dapat diperoleh hasil dari motivasi tersebut dalam bentuk keberhasilan usaha dengan memperoleh omset atau pendapatan yang maksimal. Jadi, motivasi menjadi kunci dari sebuah keberhasilan usaha yang diharapkan oleh semua pengusaha, pedaganag, dan lain sebagainya.

\section{Pengujian hipotesis (uji parsial)}

Uji $t_{\text {hitung }}$ ini digunakan untuk menjawab hipotesis pertama dan kedua $\left(\mathrm{H}_{0}\right.$ dan $\mathrm{H}_{1}$ ). Pengujian dilakukan dengan membandingkan nilai $t_{\text {hitung }}$ dengan $t_{\text {tabel }}$ pada derajat kesalahan $5 \%(\alpha=0,05)$. Apabila $t_{\text {hitung }}>t_{\text {tabel }}$, maka variabel bebas memberikan pengaruh positif dan signifikan terhadap variabel terikat. Penelitian ini dilakukan terhadap 57 orang responden $(n=57)$. Besaran derajat kebebasan (DK) dengan ketentuan $\mathrm{n}-2=57-2=55$. Dari ketentuan tersebut diperoleh data $t_{\text {tabel }}$ sebesar 1,673. Selanjutnya, untuk melihat besarnya pengaruh, digunakan angka Beta atau Standardized Coefficient (Jonathan Sarwono,2007). ditunjukkan dengan nilai thitung motivasi sebesar 5,368 atau $5,368 \%$ maka diperoleh bahwa nilai thitung $>$ ttabel $(5,368>1,673)$, artinya secara parsial variabel motivasi berpengaruh nyata terhadap keberhasilan usaha para pedagang di Pasar Parit II Kuala Tungkal Jambi. Artinya $\mathrm{H}_{\mathrm{o}}$ diterima; H0 : Motivasi berpengaruh positif dan signifikan terhadap keberhasilan usaha para pedagang di Pasar Parit II Kuala Tungkal Jambi.

\section{KESIMPULAN DAN SARAN}

\section{Kesimpulan}

Berdasarkan Karakteristik responden pedagang di Pasar Parit II Kuala Tungkal Jambiyang berjumlah 57 orang ini pedagang di Pasar Parit II Kuala Tungkal Jambi dapat didefinisikan dalam karakteristik responden berdasarkan jenis kelamin, umur, tingkat pendidikan, lama bekerja dan omset per bulan. Berdasarkan hasil analisis regresi linier sederhana bahwa keberhasilan usaha para pedagang akan meningkat setelah diperoleh dari koefisien regresi variabel motivasi sebesar 0,600 pada tingkat signifikansi 0,000 di bawah 0,05 yang artinya bahwa variabel motivasi berpengaruh posistif dan signifikan terhadap keberhasilan usaha para pedagang di Pasar Parit II Kuala Tungkal Jambi.

\section{Saran}

Pengaruh motivasi terhadap keberhasilan usaha para pedagang di Pasar Parit II Kuala Tungkal Jambi sangat signifikan, disarankan untuk Pemerintah Kabupaten berperan aktif untuk membantu meningkatkan kesejahteraan pedagang berupa fasilitas, sarana prasarana, permodalan, dan keamanan diseluruh pasar-pasar yang ada di ruang lingkup pemerintahan Kabupaten Tanjung Jabung Barat. Penelitian ini diharapkan bisa menjadi acuan bagi para pembacanya sehingga menambah wawasan tentang sejauh mana motivasi dapat mempengaruhi keberhasilan usaha, baik di bidang perdagangan di pasar maupun di tempat-tempat lainnya. 


\section{DAFTAR PUSTAKA}

Amaliawiati, Lia dan Murni, Asfia. 2014. Ekonomi Mikro. Bandung: PT. Refika Aditama.

Danil, Wahyu. (2013). Pengaruh pendapatan terhadap tingkat konsumsi pada pegawai Negeri Sipil di Kantor Bupati Kabupaten Bireuen, Jurnal Ekonomi Universitas Almuslim Bireuen.

Ghazali, Imam. 2008. Model Persamaan Struktur Konsep dan Aplikasi Dengan Program AMOS 16.0. Badan Penerbit Universitas Diponegoro: Semarang.

Mankiw, N. Gregory. (2006). Principles of ekonimics, pengantar ekonomi mikro. Jakarta: Salemba Empat.

Muana, Nanga. (2005). Makro Ekonomi, Masalah dan Kebijakan, Edisi Kedua. PT. Raja Grafindo Persada. Jakarta.

Nitisusastro, Mulyadi. (2013). Perilaku konsumen dalam perspektif kewirausahaan. Alfabeta: Bandung.

Rosyidi, Suherman. (2011). Pengantar teori ekonomi. Jakarta: PT. Raja Grafindo Persada.

Samuelson, Paul A dan Willian D. Nordaus. (2004). Makro Ekonomi Edisi 14. Alih Bahasa Haris Munandar dkk. Jakarta: PT. Gelora Aksara Pratama.

Sugiyono. (2014). Metode penelitian bisnis. Bandung: Alfabeta.

Sutrisno. (2012). Manajemen keuangan teori, konsep dan aplikasi. EKONESIA. Yogyakarta.

Umar, Husein. (2005). Metode penelitian untuk skripsi dan tesis bisnis. Jakarta: PT. Raja Grafindo Persada. 